\title{
ENTREPRENEURIAL INNOVATION AND SME GROWTH IN SOUTH SOUTH, NIGERIA
}

Department of Management, Faculty of Business Administration. University of Nigeria, Enugu Campus (UNEC)

\section{Uzoamaka, Okechukwu, Elizabeth, PhD}

Department of Business Administration, Enugu State University of Science and Technology, Enugu State, Nigeria

\section{Marcel Chinemere Okeke PhD}

mc.okeke@coou.edu.ng or mcokekeofficial@gmail.com 08034199181, 07011191777

Business Administration Department, Chukwuemeka Odumegwu Ojukwu University, Anambra State Nigeria

\begin{abstract}
This paper assessed Entrepreneurial Innovation and SME growth in South-South Nigeria with new product/service introduction and product/service improvement as specific objectives while sales growth and new customer base generation as dependent variables within $2006-$ 2016 This study adopted descriptive survey design with sample size of 566 drawn from population of 5874 staff of selected SMEs. The instrument for data collection was structured questionnaire. Hypotheses were tested with inferential statistics of linear regression and correlation. Findings indicated that new products/services introduction significantly increases sales growth $\left(\mathrm{r}=.655 ; \mathrm{r}^{2}=.429 ; \mathrm{F}=195.383 ; \mathrm{T}=13.978 ; \mathrm{p}=.000\right)$ and that product/service improvement/ significantly affects customer base generation $r=.855 ; \mathrm{r}^{2}=.731 ; \mathrm{F}=706.173$; $\mathrm{T}=26.574 ; \mathrm{p}=.000$ ). The study concluded that Entrepreneurial Innovation significantly affects SME growth in South-South Nigeria. The study recommended that the management of SMEs should strategically engage in new product/service development and product/service improvement as they would create new markets, thereby ensuring sales growth for such organizations.
\end{abstract}

Keywords: Entrepreneurial Innovation, new product/service introduction product/service improvement and Small-Medium-Enterprise (SME) Growth,

\section{INTRODUCTION}

The past six decades have witnessed growing studies on entrepreneurship in developed and developing countries. The growth of empirical studies within the innovation framework is one of the most significant developments in expanding the frontier of knowledge in the field of entrepreneurship. Entrepreneurial innovation is the means by which the entrepreneur either creates new wealth - producing resources or endows existing business with enhanced potential for creating wealth (Romero and Martin-Roman, 2012). Entrepreneurial innovation is also the successful adoption of new ways of doing things by the entrepreneur. In other words, innovations are new things applied in the business of production, distribution, and consumption of products or services. Eselemor, (2010) affirms that innovation is a specific 
function of entrepreneurship whether in an existing business or a new venture by an individual.

Historically, entrepreneurial innovation is associated with Schumpeter, whose research efforts since 1930s have continued to make significant contributions to entrepreneurship development in particular and economic development in general in developed and developing economies. His ideas and principles of organizational and national economic growth have been useful guide to big and small businesses on survival and resilience. Hence Schumpeter (1934s) identified five types of innovation which includes introduction of new goods, an improvement in the quality of existing goods, introduction of a new method of production, opening of a new market, conquest of a new source of supply of raw-materials or halfmanufactured goods and creation of a new type of industrial organization.

Similarly, the success of the emerging BRICS (Brazil, Russia, India, China and South Africa) economies has been, among other factors, traced to the growth of the small and mediumenterprises, as they are perceived as the engine room of industrial and technological advancement. Small and medium enterprises have been considered one of the driving forces in the economy due to their numeral contributions in terms of innovations, employment generation, and export promotion to list a few (Bala-Subrahmanya, Mathirajan, and Krishnawamy, 2010).

In contrast, entrepreneurship in SMEs sector in Nigeria is not as developed as its counterparts in the industrialized nations. Consequently, the performance of the SMEs sector in Nigeria is unfortunately and comparatively low, which have been blamed on environmental constraints and the entrepreneurs' attitude towards innovation (Funsho, 2010)). Which made Funsho (2010) to assert that business enterprises in this part of the world need to constantly innovate in order to ensure growth thus Freeman (1982) asserts that to choose to be non- innovative is to choose death to an organization.

Burrone and Jaiya (2005) state that the ability of firms to innovate varies significantly depending on their sector, size, focus, resources and environment in which they operate. Agarwal and Ashwani (2008) argue that globalization has affected not just the competitiveness of SMEs, but has also threatened the survival of some of them and forced them to modify their manufacturing and marketing strategies. They recommend that SME's need to establish intense linkages with R\&D (Research and Development) institutions in order to carry out technology upgrade in the long term in order to overcome the rapid technological obsolescence in the globalized economy.

In the Nigerian context, there is a growing stock of literature on entrepreneurship in SMEs, especially with regard to factors influencing its performance such as start-up capital, government policies, psychographic and demographic variables, state of infrastructures, etc. as revealed in the empirical studies of Wandi (2013); Eselemor (2010); Etuk (2008); Baridam (2001); to mention but a few. As notable as most of the empirical studies on SMEs are, the innovation dimension and its influence on the performance and growth of SMEs in Nigeria appears not to have stimulated sufficient empirical interest. Yet, innovation has been found to be an important predictor of growth in the SMEs in many countries. (Martins and Namusonge, 2014); Welsch, Price and Stoica, (2013); Subrahmanya et al (2010).

So far, studies on innovation and growth have focused on large-scale organizations, especially in the developed economies, but there is limited empirical evidence of the phenomena in the SMEs in Nigeria. In the same vein, various dimensions of entrepreneurship in the SMEs sector such as funding, demographic profiles, psychographic variables, personality traits, functional role and leadership have been explored with a view to predicting entrepreneurial success and growth. However, extant literature in entrepreneurship in Nigeria did not consider the innovation-organizational growth relationship. Thus, there is need to direct an empirical effort at this under-researched area. 


\section{Statement of the Problem}

There is concern over the growth of Small and Medium Enterprises in many nations because their growth through profit, expansion, sales and market share make significant contributions to the GDP. The adoption of innovative ways of doing business ideally is meant to enhance the performance of small and medium enterprises. When small and medium businesses innovatively change their business processes, the tendency to increase performance is often experienced or expected.

Despite its pervasiveness and recognition as the largest source of employment, the performance of the SMEs sector in Nigeria is comparatively low compared to its counterparts in advanced countries and emerging economies such as Brazil, Russia, India, China and South Africa.

In Nigeria, the failure of small and medium enterprises within the last few decades due to shortage of fund to adequately finance or adopt innovative methods of conducting their businesses. Faced with global competition as majority lacks the capacity for innovativeness. In a similar vein, many SMEs in the country experience draw back in their performance possibly due to lack of innovativeness in terms of product. New product introduction or product improvement has remained a cardinal point of innovativeness among organizations. In today competitive business environment, organizations that consistently introduce new products or commit to improving an existing product remain relevant in the business environment, but the lack of technical expertise among the management of small and medium scale enterprise, it has been observed that, many at times, the SMEs cling to their old product without alignment to changes in consumer tastes. This challenge encompasses the possibility of reducing organizational performance. Low performance which characterizes many SMEs in Nigeria finds expression in low sales and declining profit. Consequently, some employees are laid off (loss of employment) and in some cases, businesses collapse, with serious implications for the firm and the economy (Eselemor, 2010).

\section{Objectives of the Study}

This study is designed to evaluate entrepreneurial innovation and SMEs growth in SouthSouth region of Nigeria. The specific objectives of the study are to:

1. Determine the extent to which new product/service introduction increases sales growth within 2006 - 2016

2. Ascertain the effect of new product/service improvement on customer base generation within $2006-2016$

\section{Research Questions}

1. To what extent does new product/service introduction enhance sales growth within $2006-2016 ?$

2. To what extent does product/service improvement affect customer base generation within $2006-2016 ?$

\section{Research Hypotheses}

1. new product/service Introduction does not significantly increase sales growth within 2006 $-2016$

2. Product/services improvement does not significantly affect customer base generation within 2006 - 2016. 


\section{REVIEW OF RELATED LITERATURE}

\section{The Concept of Entrepreneurial Innovation}

Schumpeter (1934) perceives innovation as the major characteristic of entrepreneurship. In spite of various perspectives of scholars, views there are a consensus that innovation is at the heart of entrepreneurship (Newmann, 2012). The term "innovation" was used for the first time by Schumpeter at the beginning of the 20th century. For which his ideas and research have been developed by a number of other authors. Schumpeter defines innovation as product, process and organizational changes that do not necessarily originate from new scientific discoveries (Žižlavský, 2011), but may arise from a combination of already existing technologies and their application in a new context (Žižlavský, 2011).

Innovation is perceived by some scholars as being synonymous with change, which may be incremental, or radical, evolutionary or revolutionary, enabling or disruptive (Pearson, 1991). These manifestations usually have different effects on producers and users. Thus, innovation facilitates the translation of ideas into products, processes or markets. It is the successful adoption of new ways of doing things or new products. Drucker (1985) asserts categorically that innovation is the purposeful and organized search for changes and a systematic analysis for the opportunities such changes offer management for economic and social development.

Although, some people contend that creativity and innovation are synonymous, they are indeed different. Creativity refers to the generation of novel ideas while innovation refers to making money with the ideas so generated. Creativity is thus the starting point of any meaningful innovation. Which is the handwork that follows a conceived idea and usually involves the labour input of many people with varied, yet complementary skills. The challenge is, therefore, to transform creative ideas into tangible products or processes that will improve customer products, cut costs and/or generate new earnings for an organization (Rosenfeld, 1984; Servo, 1988). Functionally, innovation relates to some critical creative elements, which could be expressed as: Dimensions of Entrepreneurial Innovation.

\section{Dimensions of Entrepreneurial Innovation in SMEs}

Early research has examined the important role of innovation within entrepreneurship (Schumpeter, 1947). Many dimensions of entrepreneurial innovation have been explored in many studies. Susman, Warren and Ding (2006) argue that the attributes and environments of SMEs vary considerably and therefore influence the types of innovation they adopt. Although they perceive that innovation in products, processes, or services of varying types and degrees can be appropriate for different SMEs, they argue that no one option is right for all SMEs.

Susman, et al (2006) identify five dimensions of innovation (product, service, process, technological and marketing innovations whereas Martins and Namusonge (2014) identify three dimensions of innovation, product, process and technological innovations.

\section{Product/service Improvement}

Product/service improvement otherwise known as product innovation. Schumpeter (1934) defines product innovation as the introduction of a new good in which the consumers are not yet familiar with. It is a new quality of a good. Product innovation also greatly influences businesses today. Product innovation is the introduction of new functions, enhanced performance or the addition of new features into the existing products (Susman, 2006).

Raymond (2002) defines product innovation "as all the activities involved in applying new ideas and creativity to develop new product, improvement on or modification of the existing product in a way that is perceived as new by customers or consumers, which provides strategic advantage and profit for the organization”. Begemann,(2006) captures product innovation situation in these words; When existing products are no longer profitable or have been 
replaced by competitive offerings, organizations need a flow of new products to achieve longterm growth and profitability (Begemann, 2006).

\section{Service Innovation}

Some definitions of service innovation taken from the research literature include: the development of service products which are new to the supplier (Johne and Storey,1998) or an offering not previously available to a firm's customers, resulting from additions to or changes in the service concept (Menor, 2002). Encompassing ideas, practices or objects which are new to the organization and to the relevant environment, that is to say to the reference groups of that innovator (Crawford and Benedetto, 2003).

Susman et al (2006) assert that one way that SMEs can achieve such growth is by adding services to or around their products. They identify many reasons why the addition of services can provide significant growth opportunities, greater stability, and higher profit margins to SMEs (Reinartz and Ulaga, 2006).

\section{Improved Method of Production/Service Provision}

Improve method of production/service provision also known as process innovativeness is related to the introduction of new production methods, new management approaches and new technologies that can be used to improve production and managerial processes. SMEs can introduce process innovation to enhance the capability of their production processes or their supply chain operations (e.g., increased reliability or reduced cost). These innovations are developed for their own use; in-house engineering is used to customize them to suit specific applications (Susman et al, 2006).

\section{The Relationship between Product Innovation and Organizational Growth}

With innovation, quality of products could be enhanced, which, in turn, contributes to firm performance and, ultimately, to a firm's competitive advantage (Walobwa et al., 2013). Bayus, Erickson and Jackson (2003) prove that product innovation had positive and significant link with organisational performance. Also, Coad and Rao (2008) confirm a significantly positive impact of product innovation on firm performance. Similarly, CalestousJuma and Lee Yee-Cheong (2006) found that both product innovation dimensions (efficacy and efficiency) were strongly and positively related to firm performance. Furthermore, the introduction of a novel product was confirmed by Varis and Littunen (2010) to be positively associated with firm performance. Moreover, Walker (2005) conducted comparative research on the effects of product and process innovations on firm performance. They indicated that particular product improvements are positively associated with firm growth.

\section{Small-Scale Business}

The concept of small-scale business does not have a universally accepted definition, and any attempt to give an all-embracing definition may be academically futile. The reason is simple: what constitutes a small business depends upon the level of industrialization and development in a particular country. However, some definitions of the concept are necessary so as to give an idea of the subject matter.

Although there is no generally accepted defined of small business enterprise, scholars however, agree that the small scale operation possesses certain characteristics irrespective of definition.

Awujo and Urieto (1995) highlight three basic characteristics of a small scale business. They are as follows:

a) The managers being the owners 


\section{b) Capital being supplied and the ownership held by an individual or a small group.}

c) The area of operation being mainly, but the market need not being, local.

\section{Small Medium-Enterprises SMEs}

Medium-sized firms have not been greatly covered in managerial studies literature. Firstly, because it is difficult to define they and researchers must have a precise definition of their subject before beginning their study (Horace, 2002). Secondly, medium-sized firms are not studied much because they have mixed characteristics, some typical of small businesses and others which make them similar to large companies. Therefore, some writers on the subject have considered that the best way to deal with them was either to position them in the category of small businesses or in that of large companies. Lastly, medium-sized firms, no matter how defined, are few in number and they like to keep a low profile. Often these firms are run by entrepreneurs who are very reserved and who do not believe that there is any advantage in either themselves, or their management models, becoming more widely known. This conservative attitude, even if it is not one of outright distrust, certainly does not encourage researchers to engage in the pursuit of in-depth knowledge of these types of enterprises (Ariyo, 2007).

\section{Theoretical Framework}

\section{Schumpeter' Theory of Innovation}

The concepts of innovation and entrepreneurship are probably Schumpeter's most distinctive contributions to economics (Hamel and Green, 2007) role of innovation ("new combinations") and entrepreneurship in economic growth. Schumpeter highlighted the function of entrepreneurs who carries out new combinations. He viewed the occurrence of discontinuous and "revolutionary" change as the core of "economic development" which breaks the economy out of its static mode ("circular flow") and sets it on a dynamic path of fits and starts. Accordingly, consumer preferences are already given and do not undergo spontaneously. It means that they cannot be the cause of economic change. Moreover, consumers in the process of economic development play a passive role.

In Theory of economic development and further work: Schumpeter described development as historical process of structural changes, substantially driven by innovation which was divided by him into five types; launch of a new product or a new species of already known product; application of new methods of production or sales of a product (not yet proven in the industry); opening of a new market (the market for which a branch of the industry was not yet represented); acquiring of new sources of supply of raw material or semi-finished goods and new industry structure such as the creation or destruction of a monopoly position.

Schumpeter argued that anyone seeking profits must innovate. That will cause the different employment of economic system's existing supplies of productive means. Schumpeter believed that innovation is considered as an essential driver of competitiveness (Wise and Baumgartner, 1999) and economic dynamics (Hamel, and Green, 2007). According to Schumpeter innovation is a "process of industrial mutation, that incessantly revolutionizes the economic structure from within, incessantly destroying the old one, incessantly creating a new one". He divided the innovation process into four dimensions: invention, innovation, diffusion and imitation. Then he puts the dynamic entrepreneur in the middle of his analysis. In Schumpeter's theory, the possibility and activity of the entrepreneurs, drawing upon the discoveries of scientists and inventors, create completely new opportunities for investment, growth and employment. In Schumpeter's analysis, the invention phase or the basic innovation has less of an impact, while the diffusion and imitation process have much greater influence on the state of an economy. 


\section{Empirical Review}

Many researchers and scholars have tried to link entrepreneurial innovation to organizational growth in terms of increase in profit, customer base, and appreciable market share Martins and Mamusonge (2014) using the survey method and questionnaire ascertained the influence of innovation on business growth of 203 SME in Kenyan SMEs in the garment manufacturing sector. They found from the managers that innovative SMEs had realized increase in sales, customer base, and change in location and profits in monetary sense. Their study also revealed that innovation had continued to influence businesses in the garment-making industry in many ways, as most of the innovations were adoptions of products, processes and technologies developed outside the country, although some firms were to come up with their own new designs, software for simple accounting and production.

The growth performance of SMEs and its relationship to innovation have been studied and analyzed in terms of sales turnover, investment, and employment. Welsch et al. (2013) in their field study of SMEs innovation sought to analyze the growth performance for all the 1120 SMEs of economic sector-for innovative and non-innovative SMEs separately and within the innovative group of SMEs. Their study revealed that Innovative SMEs were those involved in new product and process developments vis-à-vis those engaged in improvement of products and processes. For measuring growth, the researchers clubbed all the SMEs together in each sector and did not separately identify growing ones from the rest. Furthermore, when they looked at innovative and non-innovative SMEs, they measured growth for the respective group of SMEs together, without segregating growing ones from the rest. The same holds good for further analysis in terms of (i) innovative SMEs, which have claimed to have developed new products/processes and (ii) innovative SMEs, which have claimed to have only improved products/processes.).

\section{METHODOLOGY}

This study adopted descriptive survey method to generate data through the questionnaire. Primary data were obtained from the respondents through questionnaire and secondary data were generated from $r$ journals, scholarly publications in magazines, textbooks and the Internet and the financial statements of the organizations under study. The target research population of this study consists of the staff of registered small and medium- enterprises dealing on information and technology related services and products within the six states that make up the South-South geopolitical zone of Nigeria (Akwa-Ibom, Bayelsa, Cross River, Delta, Edo and Rivers) which gives a total population of 5,784 obtained from Nigerian Association of Chambers of Commerce, Industry, Mines and Agriculture (NACCIMA) Business Directory, 2016 in those States. The sample size was 566 staff of selected SMEs. The major instrument used in generating primary data for the study was structured questionnaire. The researchers established content and face validity of the instrument by submitting the instrument to experts in entrepreneurship innovative and organizational growth in well-established business organizations for their assessment, criticisms and contributions, all geared towards improving content and facial validity of the instrument. All corrections were effected before the final copy of the questionnaire was administered. To ascertain the reliability of the research instrument, a test-re-test method was adopted in which 30 copies of the questionnaire were distributed to the SMEs in various states understudy; five (5) copies each to the five managers of difference SMEs in the various states. These were collected afterwards and re-distributed for the second time. In carrying out the reliability of the research instrument, the Cronbach's Alpha was used. Cronbach's alpha $(\alpha)$ is an estimate of reliability, specifically the internal consistency, of test or scale. In order to measure internal consistency of the instrument, Cronbach alpha was applied, which gave a reliability coefficient of $\alpha=0.882$ which indicate that the instrument is $88.2 \%$ reliable. Hypotheses 
formulated were tested using inferential statistic of linear regression and correlation. Reject the null hypothesis $\left(\mathrm{H}_{\mathrm{O}}\right)$ if $\mathrm{p}<0.05$. Do not reject if otherwise.

PRESENTATION AND ANLAYSES OF DATA Questionnaire Distribution

\begin{tabular}{lll}
\hline Categories & Frequency & Percentage \\
\hline Distributed & 566 & $100 \%$ \\
Returned & 551 & $97.3 \%$ \\
Not Retuned & 15 & $2.7 \%$ \\
\hline
\end{tabular}

\section{Source: Fieldwork 2019}

In the table above, shows that 566 copies of questionnaire were distributed and 551 were properly filled and returned, while 15 of them were not properly filled, thereby rendering them invalid for the study and others not returned. Thus given $97.3 \%$ of return

\section{TEST OF HYPOTHESES}

\section{Hypothesis one}

Ho: Introduction of new product/service does not significantly increases sales growth

Hi: Introduction of new product/service significantly increases sales growth

\section{Results}

\section{Model Summary}

\begin{tabular}{|l|l|l|l|l|l|l|}
\hline Model & $\mathrm{R}$ & R Square & $\begin{array}{l}\text { Adjusted R } \\
\text { Square }\end{array}$ & $\begin{array}{l}\text { Std. Error of } \\
\text { the Estimate }\end{array}$ & Durbin-Watson \\
\hline 1 & $.655^{\mathrm{a}}$ & .429 & .427 & .82731 & .305 \\
\hline
\end{tabular}

a. Predictors: (Constant), Introduction of New Product/Service

b. Dependent Variable: Sales Growth.

\section{ANOVA}

\begin{tabular}{|ll|ll|l|l|l|l|}
\hline \multicolumn{2}{|l|}{ Model } & $\begin{array}{l}\text { Sum } \\
\text { Squares }\end{array}$ & of & df & Mean Square & F & Sig. \\
\hline \multirow{2}{*}{1} & Regression & 133.727 & 1 & 133.727 & 195.383 & $.000^{\mathrm{b}}$ \\
& Residual & 177.953 & 260 & .684 & & \\
& Total & 311.679 & 261 & & & \\
\hline
\end{tabular}

a. Dependent Variable: Sales Growth.

b. Predictors: (Constant), Introduction of New Product/Service.

\section{Coefficients}

\begin{tabular}{|ll|l|l|l|l|l|}
\hline Model & \multicolumn{2}{|l|}{ Unstandardized Coefficients } & $\begin{array}{l}\text { Standardized } \\
\text { Coefficients }\end{array}$ & T & Sig. \\
\cline { 2 - 6 } & & $\mathrm{B}$ & Std. Error & Beta & \\
\hline $\begin{array}{l}\text { (Constant) } \\
\begin{array}{l}\text { Introduction of New } \\
\text { Product/Service }\end{array}\end{array}$ & .082 & .133 & & .614 & .540 \\
\end{tabular}

a. Dependent Variable: Introduction of New Product/Service. 


$\begin{array}{ll}\text { Result } & \text { Summary } \\ \mathrm{R} & =.655 \\ \mathrm{R}^{2} & =.429 \\ \mathrm{~F} & =195.383 \\ \mathrm{~T} & =13.978 \\ \mathrm{DW} & =.305\end{array}$

\section{Interpretation of the Result}

Table 4.12 shows the descriptive statistics of the introduction of new product/service and sales growth. The result shows that introduction of new product/service has mean and SD responses of $3.16 \pm 1.39$ while sales growth has mean and SD responses of $2.97 \pm 1.15$. The standard deviation values, show that there is less difference in terms of the standard deviation scores. This implies that there is about the same variability of data points between the dependent (sales growth) and independent variables (of new product/service introduction).

A linear regression analysis conducted to determine the extent to which new product/service introduction increases sales growth (table 4.13-4.15) shows that there is strong positive relationship between introduction of new product/service and sales growth $(\mathrm{R}$ - coefficient $=$ $.655)$. The $\mathrm{R}$ square, the coefficient of determination, shows that only $42 \%$ of the variation in sales growth can be explained by new product/service introduction with no autocorrelation as Durbbin-Watson (.305) is less than 2. With the linear regression model, the error of estimate is low, with a value of about .82731. The regression sum of the square 133.727 is less than the residual sum of the square 177.953 indicating that the variation is due to chance. The Fstatistics $=195.383$ shows that the model is significant.

\section{Decision Rule}

Reject null hypothesis (Ho) if $\mathrm{P}-$ Value $<0.05$ and do not reject Ho if otherwise

\section{Decision}

Since the P-Value $000<0.05$, we reject the null hypothesis $(\mathrm{Ho})$ and then conclude that new products/services introduction significantly increases sales growth.

\section{Hypothesis Two}

Ho: product/services Improvement does not significantly affect customer base generation

Product/services Improvement significantly affects customer base generation.

\section{Results}

\section{Descriptive Statistics}

\begin{tabular}{|l|l|l|l|}
\hline & Mean & Std. Deviation & N \\
\hline Improvement in Existing Product/Services & 2.5878 & 1.37504 & 228 \\
Customer Base Generation & 3.5763 & 1.37294 & 228 \\
\hline
\end{tabular}

\section{Model Summary}

\begin{tabular}{|l|l|l|l|l|l|l|}
\hline Model & $\mathrm{R}$ & $\mathrm{R}$ Square & $\begin{array}{l}\text { Adjusted } \\
\text { Square }\end{array}$ & $\begin{array}{l}\text { Std. Error of the } \\
\text { Estimate }\end{array}$ & Durbin-Watson \\
\hline 1 & $.855^{\mathrm{a}}$ & .731 & .730 & .71467 & .380 \\
\hline
\end{tabular}

a. Predictors: (Constant), Improvement in Existing Product/Services.

b. Dependent Variable: Customer Base Generation. 


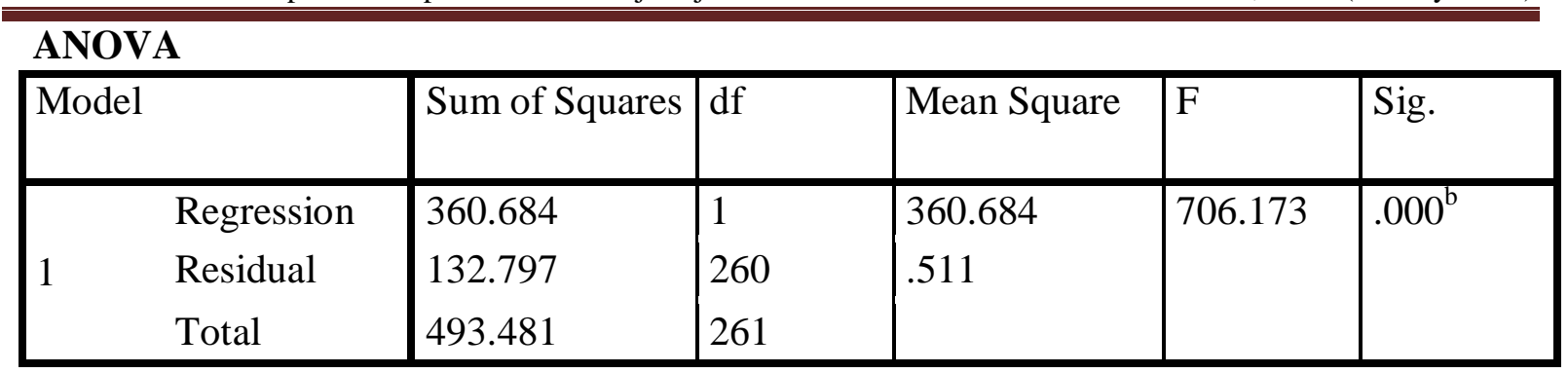

a. Dependent Variable: Customer Base Generation.

b. Predictors: (Constant), Improvement in Existing Product/Services.

\section{Coefficients}

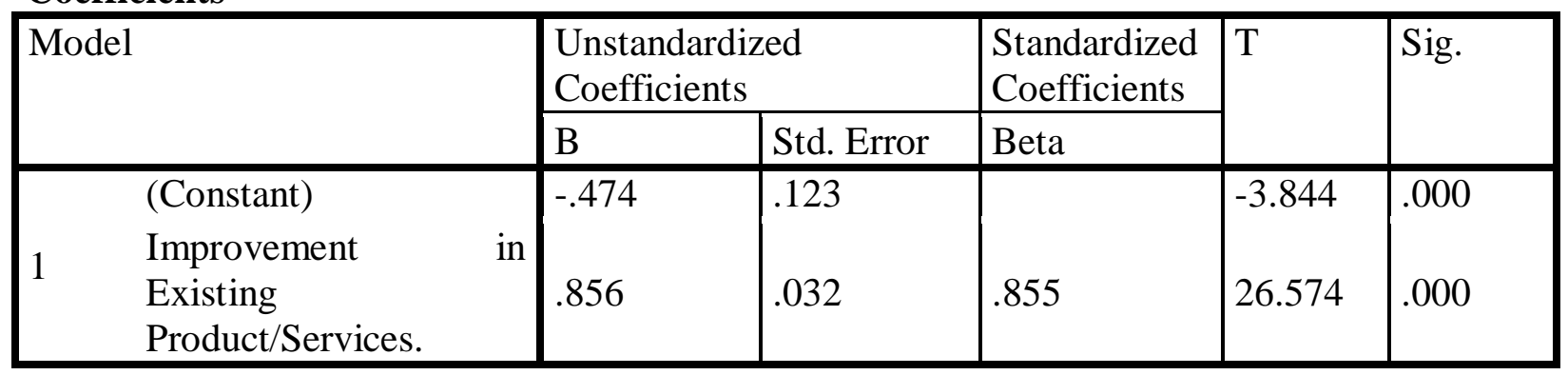

a. Dependent Variable: Customer Base Generation.

\section{Result Summary}

$\begin{array}{lll}\mathrm{R} & = & .855 \\ \mathrm{R}^{2} & = & .731 \\ \mathrm{~F} & = & 706.17 \\ \mathrm{~T} & = & 26.574 \\ \mathrm{DW} & = & .380\end{array}$

\section{Interpretation of the Result}

Table 4.12 shows the descriptive statistics of product/services improvement and customer base generation. The result shows that product/services improvement has mean and SD responses of $2.59 \pm 1.38$ while customer base generation has mean and SD responses of 3.58 \pm 1.37. The standard deviation values show that there is less difference in terms of the standard deviation scores. This implies that there is about the same variability of data points between the dependent (customer base generation) and independent variables (improvement in existing product/services).

A linear regression analysis conducted to ascertain the extent to which product/service improvement affect customer base generation (table 4.13-4.15) shows that there is strong positive relationship between improvement in existing product/services improvement and customer base generation ( $\mathrm{R}$ - coefficient $=.855$ ). The $\mathrm{R}$ square, the coefficient of determination, shows that only $73.1 \%$ of the variation in customer base generation can be explained by improvement in existing product/services with no autocorrelation as DurbbinWatson (.380) is less than 2. With the linear regression model, the error of estimate is low, with a value of about .71467. The regression sum of the square 360.684 is less than the residual sum of the square 132.797 indicating that the variation is not due to chance. The Fstatistics $=706.173$ shows that the model is significant.

\section{Decision Rule}

Reject null hypothesis (Ho) if P-Value $<0.05$ and do not reject Ho if otherwise 


\section{Decision}

Since the P-Value $000<0.05$, we reject the null hypothesis (Ho) and then conclude that improvement in existing products/services significantly affects customer base generation.

\section{Discussion of the Result}

The result of this study which sets to empirically evaluate effect of entrepreneurial innovation on SMEs growth in South-South region of Nigeria revealed the extent to which new product/service introduction increases sales growth, extent to which product/service improvement affects customer base generation. The result indicates that introduction of new product/service significantly increases sales $\left(\mathrm{r}=.655 ; \mathrm{r}^{2}=.429 ; \mathrm{F}=195.383 ; \mathrm{T}=13.978 ; \mathrm{p}=\right.$ .000). Product/service introduction otherwise known as product innovation, which indicates the introduction of new goods; In a similar term, Hambrick (1985) supported the study findings by asserting that the development of new products is an essential part of many firms' strategies for thriving or surviving in the dynamic and competitive business environment. The above views which correspond to this study findings expresses the vital role which new product plays in ensuring that organization achieve its sale growth. In other words, introduction of new product/services is paramount to SMEs in achieving sales growth which invariable translates to organizational growth. Also scholars have tried linking innovation to organizational growth. In a study by Martins and Mamusonge (2014) on influence of innovation on business growth in Kenyan SMEs in the garment manufacturing sector reported that increase in sales. This study agrees with the present study.

In addition, the study identified that improvement in existing product/services significantly affect customer base generation $\left(\mathrm{r}=.855 ; \mathrm{r}^{2}=.731 ; \mathrm{F}=706.173 ; \mathrm{T}=26.574 ; \mathrm{p}=.000\right)$. In today's highly competitive business environment, influences by consistent technological advancement and globalization, the place of product/service improvement has become inevitable. Thus organizations could attract high patronage by ensuring that their products/services match up with the changing consumers tastes which could be achieved by consistent improvement in products/services in form of design, colour, size and packaging is therefore critical to all organizations. This finding agrees with the argument by Susman et al (2006) that SMEs could engage in product innovation by introduction of new functions, enhanced performance, or added features to existing products. They observe that innovation of this type is generally incremental; arguing that the underlying technology can be new to the firm, but is unlikely to be "new to the world. In agreement, Menor et al., (2002) mentioned that service innovation entails offering not previously available to a firm's customers, resulting from additions to or changes in the service concept. Martins and Mamusonge (2014) highlight that innovative SMEs had realized increased customer base to further highlight the role of improvement in organizational product/services in customer generation.

\section{CONCLUSION}

This study concludes that business environment is characterized by business innovation which impact on the organization especially in the area of growth. Innovation in the business world brings about new method of engaging in product/service delivery in an effort to meet the ever changing consumer taste: Today, entrepreneurs have to adopt new ways of doing things in production, distribution and consumption of products and services; therefore, for an organization to survival in the current business world, the importance of innovation cannot be over emphasized. Presently customers are highly informed and more demanding than before. Responsiveness to customer needs and changing market conditions has become more important for the success of firms and calls for the introduction of new products and services together with innovation capacity for a firm. Customer personality and perception 
significantly impacts on new product/services development, adoption and improvement hence concerted effort should be directed at improving company product/service brand that are consistent with consumer taste and personality since they contribute highest and are also significant to sales growth and product success.

\section{RECOMMEDATIONS}

Based on the findings, the following recommendations were made

1 The management of various SMEs should strategically engage in new product/service development as this would create new markets for the organizations thereby ensuring rapid sales growth for such organizations.

2 The need to enhance the already existing products/services is paramount and therefore should be pursued as it would attract new customers as well as retain the already existing customers.

\section{References}

1. Agarwal, R. \& J. Ashwani (2008). The role of innovation characteristics and perceived voluntariness in the acceptance of information technologies. Decision Sciences 28(3): 557-582.

2. Ariyo, D. (2007).Small Firms are the Backbone of the Nigerian Economy. African

3. Awujo, A.C. \&Urieto, J.E. (1995), Introduction to Business, Port Harcourt: Paragraphics

4. Bala-Subrahmanya (2005): Technological innovations in small enterprises: A comparative perspective of Bangalore (India) and Northeast England (UK)'.Technovation, 25 (3): 269-80.

5. Bayus D, P. Erickson, \& Jackson, D., (2003). New Product Development in British SMEs.European Journal of Businesss Management 3(4) 212-22

6. Begemann Frederick (2006). Co-Branding as a Strategy. An Analysis from the Resource Based View Druck and Bindung; Norderstedt (Germany).

7. Burrone, E., \& G. S. Jaiya (2005).Intellectual Property (IP) Rights and Innovation in Small and Medium-Sized Enterprises Geneva: World Intellectual Property Organization.

8. CalestousJuma\& Lee Yee-Cheong (2006) Innovation: Applying Knowledge in Development. Communication Development Inc, Washington

9. Crawford, M. \& D. Benedetto (2003). New Product Management. New York, McGraw Hill

10. Drucker, P. (1985). 'Entrepreneurship and Innovation: Practice and Principles', Harper Business, New York

11. Eselemor, B. (2010). Economic development in Nigeria: The role of small business, Journal of Entrepreneurship Development, (2 (4), 36-38.

12. Freeman, C.(1982). The Economics of Industrial Innovation, $\left(3^{\text {rd }}\right.$ ed.) London: Pinter.

13. Funsho, W.B. (2010) Policy formulation and implementation in Nigeria: The growth of the industrial sector, Journal of Development, 14 (4), 75-78.

14. Hambrick, D., (1985), Innovation and Small Firms. MIT Press, Cambridge, Ma.

15. Hamel, G. \& Green, B. (2007).The Future of Management. Boston: Harvard Business School Press.

16. Johne, A. \& C. Storey (1998). New service development: A review of the literature and annotated bibliography. European Journal of Marketing 32(3/4): 184-251

17. Martins, M. S. \& Namusonge, M. J. (2014).Influence of innovation on small and medium enterprise (SME) growth: a case study of garment manufacturing industries in Nakurucounty. International Journal for Innovation Education and Research., 2 (5).3237 
18. Menor, C., (2002), 'Agglomeration Effects in Europe', European Economic Review,46, 213227.

19. Pearson -Ros, E. (1991). Explaining the Decisions to Carry out Product and Process Innovations: The Spanish Case'.The Journal of High Technology Management Research, 10 (2): $223-42$.

20. Reinartz, W. \& W. Ulaga (2006). Growth beyond the core.Financial Times (31 March 2006)

21. Romero, I. \& Martine-Roman, J. A. (2012).Self-employment and innovation.Exploring the determinants of innovative behaviour in small business. Research Policy, 41(1), 178189.

22. Rosenfeld, C. (1984). Entrepreneurship, resistance to change and growth in small firms.Journal of Small Business and Enterprise Development 9(1): 61-72.

23. Schumpeter, J.A. (1934) The Theory of Economic development: An inquiry into profits, capital, credit, interest and the business cycle, Cambridge mass: Harvard University press.

24. Schumpeter, J.A. (1947), The Theory of Economic Development, Cambridge, MA: Harvard University Press.

25. Schumpeter, J.A. (1964) The Theory of Economic development: An inquiry into profits, capital, credit, interest and the business cycle, Cambridge mass: Harvard University press.

26. Servo, H. (1988). The relational view: cooperative strategy and resources of Interorganizational competitive advantage. Academy of Management Review, 23(4), 660-679.

27. Subrahmanya, M. H., M. Mathirajan, P. Balachandra, \& K. N. Krishnaswamy (2010). Importance of TechnologicalInnovation for SME Growth: Evidence from India, UnitedNations University Working Paper:UNU World Institute for Development of Economic Research

28. Susman G, A. Warren \& D. Min (2006) Product and Service Innovation in Small and Medium sized Enterprises. US Department of Commerce, USA International Journal for Innovation Education and Research www.ijier.net (2) 5, 212-217.

29. Varis, J., \&Littunen, S., (2010), 'Regulation, Allocative Efficiency and Productivity in OECD Countries: Industry and Firm Level Evidence', OECD Economics Deaprtment, OECD, Paris. Working Paper 2010:02

30. Walker, R., (2005). Economic Development as Self-Discovery in innovation, Journal of Development Economics, 72 (2): 603-33.

31. Walobwa D, K. Ngugi, \& B. Chepkulei (2013). Effect of the Type of Innovation on Growth of Small and Meduim Enterprises in Kenya: A Case of Garment Enterprises in Jericho,NairobiEuropean Journal of Management Sciences and Economics, 1(2), 49-57.

32. Wandi, W.O. (2005). Small business development and management in developing economies, New York: McGraw-Hill Inc

33. Welsch, H., Price, D. P., \&Stoica, M. (2013).Innovation, performance and growth intentions, International Journal of Economics and Management Engineering, 3 (5), 176181.

34. Welsch, H., Price, D. P., \&Stoica, M. (2013).Innovation, performance and growth intentions, International Journal of Economics and Management Engineering, 3 (5), 176181.

35. Wise, R. \& P. Baumgartner (1999). Go downstream: The new profit imperative in manufacturing." Harvard Business Review77(5): 133-141.

36. Žižlavský D. K. (2011).SMEs and Innovation: Perceived Barriers and Behavioral Patterns. The International Journal of Entrepreneurship and Innovation, 2 (2): 111-18. 